\title{
Radio Frequency Identification (RFID) Aplication Analysis on E-Toll in Indonesia
}

\author{
Rachmad Hidayat ${ }^{1}$, Sabarudin Akhmad ${ }^{2}$ \\ \{rachmad.hidayat@trunojoyo.ac.id ${ }^{1}$ \} \\ ${ }^{1,2}$ Department of Industrial Engineering,University of Trunojoyo, Madura, Indonesia
}

\begin{abstract}
This study researched the application of RFID applications to e-toll. This study analyzed the effect of perceived usefulness, brand image, and perceived risk to purchase decision either directly or indirectly with customer perceived value mediated. This research used Structural Equation Model (SEM) method. The results showed that there was significant influence perceived usefulness to purchase decision directly or mediated by customer perceived value. The effect of brand image on purchase decision directly was non-significant but significant if customer perceived value mediated. There was a significant direct influence perceived risk to purchase decision but non-significant if mediated by customer perceived value. Managerial implication of RFID application on etoll was customer got easy of transaction, customer did not need to carry money while transaction and customer did not have long queue when did the transaction at toll gate.
\end{abstract}

Keywords: Perceived usefulness, brand image, perceived risk, customer perceived value, purchase decision.

\section{Introduction}

In the national strategic project target, toll projects take a portion of 20 percent. The toll road projects that are the concern of the government are Trans Java Toll Road and Trans Sumatera Toll Road. The government was targeting to build $1,854.5 \mathrm{~km}$ of toll roads within five years. Long construction spread over several islands, such as Sumatera Island as much as $496 \mathrm{~km}$, Java Island $914 \mathrm{~km}$, the rest in Kalimantan and Sulawesi. Toll road construction is also accompanied by increased innovation and toll road services in Indonesia. The use of information system technology is necessary to improve productivity and efficiency. One of the emerging technologies in toll road services is the use of Radio Frequency Identification.

Radio Frequency Identification is a technology that uses radio frequencies to identify objects automatically (Nam et. al., 2017; Alwadi et. al., 2017). Radio Frequency Identification is a technology that automatically stores data where RFID can read tags at a certain distance without direct contact (Want, 2004; Woods et. al., 2003). One of the areas that have implemented Radio Frequency Identification is electronic toll collection. Electronic Toll Collection is a technology used to collect toll payments in order to reduce congestion and speed up the toll payment process (Dhurat et. al., 2014). With the use of Electronic Toll Collection payment system will make the payment process will be easier to use and faster in the payment process. Electronic Toll Collection Implementation in Indonesia is on an e-toll.

E-toll is a product of new payment innovation technology as a tool for paper ticket replacement transactions normally found by toll road users. E-toll is expected to reduce the traffic problem at the toll gate with the use of information technology, which will increase toll transaction and toll service speed in Indonesia. From October 2017, all toll gates in Indonesia are not serving cash transactions. In addition to reducing the queue, electronic transaction 
services at all toll gates which aim to improve cashless society. E-toll transactions involve the use of Internet networks such as digital price storage systems or commonly referred to as electronic money.

There are several banks that issue e-toll products. Competition between banks as e-toll issuers is also becoming more intense. Customers are more selective in choosing and purchasing products that have a good brand image. A good brand image can degrade a customer's bad perception of the risks to be obtained from the purchased product (Lee and Tan, 2003; Teas and Agarwal, 2000) or increase the perception of the product value that the customer will acquire from the purchased product (Loudon and Bitta, 1988; Romaniuk and Sharp, 2003). Purchase decision can arise if there is stimulation that can push the happening of the purchase decision which is customer perceived value. The purpose of this research was to know customer readiness in Indonesia in the application of RFID on e-toll. This study analyzed the effect of perceived usefulness, brand image, and perceived risk to e-toll epurchase decision in Indonesia through customer perceived value.

\section{Methods}

Based on the literature review, a research framework can be developed as shown in Figure 1.

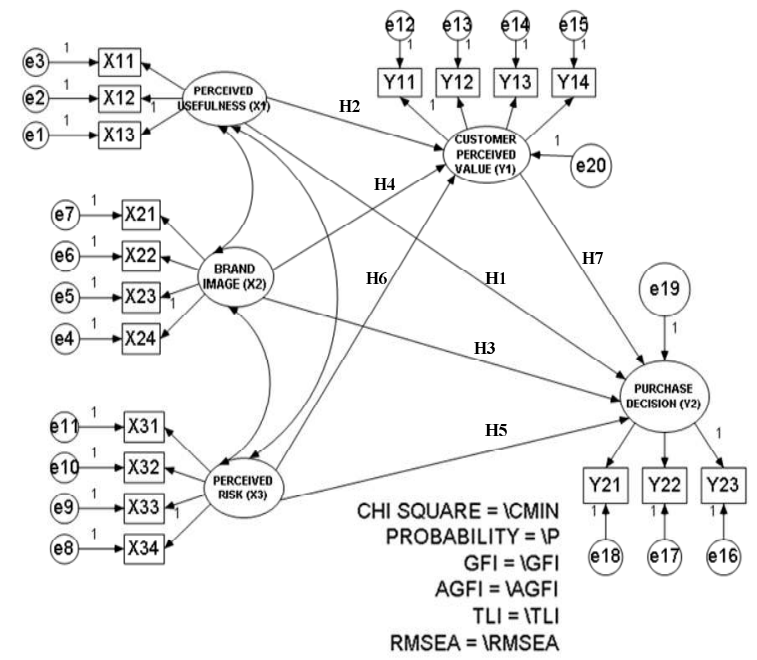

Fig. 1. Theoretical Thinking Framework.

The independent variables in this study are Perceived usefulness $\left(\mathrm{X}_{1}\right)$ with indicators of increasing transaction effectiveness $\left(X_{1.1}\right)$, usefulness $\left(X_{1.2}\right)$, increasing efficiency $\left(X_{1.3}\right)$ (Elkaseh et. al., 2016). Brand image $\left(\mathrm{X}_{2}\right)$ with customer-recognizable easiness indicator $\left(\mathrm{X}_{2.1}\right)$, has an up to date model $\left(\mathrm{X}_{2.2}\right)$, can be used properly/useful $\left(\mathrm{X}_{2.3}\right)$, familiar to customer $\left(\mathrm{X}_{2.4}\right)$ (Low and Lamb, 2000). Perceived risk $\left(\mathrm{X}_{3}\right)$ with financial risk indicators $\left(\mathrm{X}_{3.1}\right)$, physical risk $\left(\mathrm{X}_{3.2}\right)$, functional risk $\left(\mathrm{X}_{3.3}\right)$, psychological risk $\left(\mathrm{X}_{3.4}\right)$ (Pires et. al., 2004). Interval variable in this research is Customer Perceived Value $\left(\mathrm{Y}_{1}\right)$ with indicators of emotional value $\left(\mathrm{Y}_{1.1}\right)$, functional value $\left(\mathrm{Y}_{1.2}\right)$, social value $\left(\mathrm{Y}_{1.3}\right)$, economical value $\left(\mathrm{Y}_{1.4}\right)$ (Sweeney and Soutar, 2001). Dependent variable in this research is Purchase decision $\left(\mathrm{Y}_{2}\right)$ with indicators of product selection according to requirement $\left(\mathrm{Y}_{2.1}\right)$, product quality and benefit information $\left(\mathrm{Y}_{2.2}\right)$, stability of product $\left(\mathrm{Y}_{2.3}\right)$ (Armstrong and Kotler, 2011:80). 
The hypotheses proposed in this study are:

H1: Perceived usefulness positively influences purchase decision produk e-toll

$\mathrm{H} 2$ : Perceived usefulness positively influences customer perceived value e-toll

H3 : Brand image positively influences Purchase decision e-toll

H4 : Brand image positively influences Customer perceived value e-toll

H5 : Perceived risk positively influences Purchase decision e-toll

H6 : Perceived risk positively influences Customer perceived value e-toll

H7 : Customer perceived value positively influences purchase decision e-toll

The population in this study were customers who had purchased e-toll (Mandiri e-Toll card, Indomaret Card, Mandiri e-money, and GazzCard) and used it for toll payment transactions. The sample in this study were 180 respondents who had bought and used e-toll for toll payment transaction in 4 big cities in Indonesia (Jakarta, Bandung, Semarang, and Surabaya). The sampling method used non-probability sampling with purposive sampling technique. Data were obtained from the questionnaire distribution. The analysis technique used in this research was Structural Equation Model which was operated through AMOS 20.0 program. The reason for using SEM, because SEM is a set of statistical techniques that allows the measurement of a relatively complex set of relationships simultaneously. Structural Model is a model of relationship structure that forms or explains causality between factors (Ghozali, 2011:152).

\section{Analysis}

\subsection{SEM Analysis}

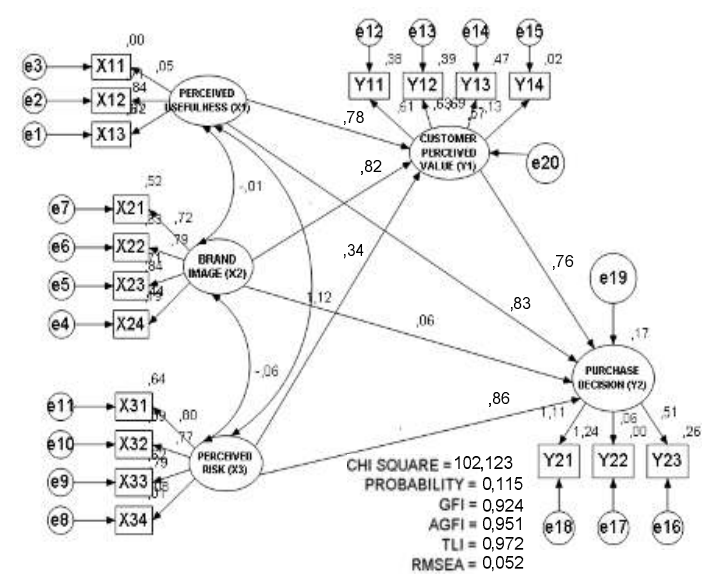

Fig. 2. Results of SEM analysis.

The hypotheses were tested by examining the partial test of each direct effect path as shown by the results of SEM analysis. Indirect effects are the carried-away results of the test of direct effects. The hypothesis of direct effects was tested by examining the CR value, in which $\mathrm{CR}$ value $>1.96$ and $P<0.05$ means a significant effect. Table1. shows the results of hypothesis testing. 
Table 1. The results of hypothesis testing.

\begin{tabular}{cllrc}
\hline $\begin{array}{c}\text { Hypo- } \\
\text { thesis }\end{array}$ & \multicolumn{1}{c}{$\begin{array}{c}\text { Independent } \\
\text { Variables }\end{array}$} & $\begin{array}{c}\text { Dependent } \\
\text { Variables }\end{array}$ & Path Coef. & Result \\
\hline H1 & Perc. usefulness & Purchase decision & 0.83 & Significant \\
\hline H2 & Perc. usefulness & Cust. Perce. value & 0.78 & Significant \\
\hline H3 & Brand image & Purchase decision & 0.06 & $\begin{array}{c}\text { Non } \\
\text { Significant }\end{array}$ \\
\hline H4 & Brand image & Cust. Perce. value & 0.82 & Significant \\
\hline H5 & Perce. risk & Purchase decision & 0.86 & Significant \\
\hline H6 & Perce. risk & Cust. Perce. value & 0.34 & $\begin{array}{c}\text { Non } \\
\text { Significant }\end{array}$ \\
\hline H7 & Cust. Perce. value & Purchase decision & 0.76 & Significant \\
\hline
\end{tabular}

\subsubsection{The influence of Perceived usefulness on purchase decision directly or mediated by customer perceived value}

The test results of the research showed that perceived usefulness had a positive and significant effect on the purchase decision, either directly or indirectly, mediated by customer perceived value. The higher the perceived usefulness of the e-toll product customer, the higher the purchase rate of the e-toll product. The higher the perceived usefulness of the e-toll product the higher the customer perceived value of the e-toll product. If an e-toll product provides a variety of benefits to its users, then users will be happy to use e-toll products. This will directly affect the interest of using e-toll products. Conversely, if the users assume that the e-toll product does not provide any benefit to them, then the user will no longer interested to use e-toll products because there are various options of non-cash transaction tools.

The categorization of perceived usefulness in this study showed that respondents rated etoll products as having high benefits. Perceived usefulness of e-toll products can improve customer perceived value of e-toll products. Customers perceive that e-toll products provide various advantages of high benefits such as providing speed and accuracy in transactions, can be used for any transaction that is of little value or with high frequency, practical and easy to use for transactions, and more efficient than cash.

This study is in accordance with Davis's theory which stated the perception of utility as constructing one's belief that the use of a particular technology will be able to improve their performance (Davis, 1989). If concluded from the previous theory, perceived usefulness is a person's belief in a technology that will have a positive impact on performance improvement when it is useful for users of these technologies. The benefit of using a product or service is a useful value that will be obtained or expected by the user in conducting various transactions. The result of this study is in accordance with the research of Juniwati which showed that perceived usefulness had a positive and significant effect on purchase decision (Juniwati, 2014).

\subsubsection{The influence of Brand Image on purchase decision directly or mediated by customer perceived value}

In the e-toll purchase decision, the customers set up e-toll brands in the set of choices and form customer perceived value. Usually, customers will choose the preferred brand but there are also factors that influence such as the attitude of others and the factors of unforeseen circumstances. Customers who have a good customer perceived value of e-toll will also 
influence the purchase decision e-toll. Brand image is a concept created by customers for their subjective reasons and personal emotions (Fianto et. al., 2014). In addition, the brand image is the brand perception that the brand association describes in the customer's memory. A good brand image of e-toll will improve a good perception of customers as well. In this study, brand image e-toll has no significant effect on customer purchase decision to e-toll. The result of this study is in line with the findings of Rossi's research which stated that the products affected the purchase decision and brand image had no effect on purchase decision (Rossi et. al., 2015).

The results of this study contradict with Wu's research which showed that brand image and price were simultaneously positively influence purchase decision (Wu et. al., 2011). Brand image affected purchase decision (Jalilvand and Samiei, 2012). Managers can enhance their brand image by improving products, improving product quality, offering products at reasonable prices, and being friendly in providing services. These improvements directly increase the purchase decision of the product. Brand image positively affects the purchase decision. Well-managed brand associations which include enhanced functional, symbolic and experience benefits will produce a good brand image (Chiang and Jang, 2007). Brand image had a positive influence on purchase decision ( $\mathrm{Wu}, 2015)$. Based on this, companies build a specific brand image, as brand image can be perceived and linked by customers will have a positive influence on purchase decision. Brand image that can be perceived and linked by the customer will influence customer purchase decision positively (Lien et. al., 2015).

Without the brand image, there will be no communication effect for customers to buy a product with a particular brand. Customers must be notified of the trademark. Brand image cannot be formed from the desire to buy and cannot occur if customer perceived value in a brand does not exist (Nandan, 2005). Thus, the results of this study proved that brand image positively influences buying interest if mediated by customer perceived value. The result of this study is in line with Godey's research which stated that brand image is an important cue during the customer's purchasing decision process (Godey, 2012). Profitable brand information will positively affect the perception of quality, value perception, and the willingness of customers to buy. Customers are more likely to buy products with a wellknown brand that has a positive brand image because the brand with a more positive image has the effect of reducing the risk perceived by customers (Lee and Tan, 2003).

Brand image is an important construction that encourages customers when making decisions to choose. The company creates a picture and message that associates the company and its products by adding feeling value and delivering the brand as an experience that combines all the elements of value (Cretu and Brodie, 2007). Brand image plays a role in creating value and building customer perceived value and indirectly determining the purchase decision of the product or service. Customers should consider the role of brand image and customer perceived value in service purchasing decisions, especially for technology-oriented products or services and most importantly the results show that value plays a very important role in generating positive results for service companies (Liu et. al., 2015).

The result of this study is in accordance with the findings of research conducted by Ryu et. al., (2012) which found that Brand image positively influences customer perceived value. Brand image positively affects the price and value that the brand image shows the expected and reputable brand to increase the price level and increase the value of the product or service (Lien et. al., 2015). Brand image positively affected the perception of price and customer perceived value. Brand image that shows the expected and reputable brand increases the price level and increases the value of the product or service (Lai et. al., 2009). 


\subsubsection{The influence of Perceived risk on purchase decision directly or mediated by customer perceived value}

In addition to perceived usefulness and brand image factors which affect the purchase decision is perceived risk. Although e-toll provides many benefits and ease of use to its users, there are still some customers who refuse to use e-toll because of uncertainty and security issues (Kuisma et. al., 2007; Littler and Melanthiou, 2006). One of the factors that can affect customer perceived value is perceived risk. According to Pavlou (2001), perceived risk is a state of uncertainty that customers consider to decide "yes" or "no" to make transactions. This security risk factor needs to pay attention by e-toll issuers in order to minimize customer's negative perception. E-toll issuers must provide transaction risk information that may occur, in order to prevent customers from having worry about e-toll transaction. Some of the risk factors that can occur by e-toll users namely errors in entering numbers or codes when refilling e-toll due to user error or because the facility is not maximized and only focused on some major cities only.

Perceived risk is an unexpected consequence that customers want to avoid when buying and using products (Hirunyawipada and Paswan, 2006). Overall, unexpected risks include customer knowledge and trust about unintended consequences, which include negative affective responses associated with unpleasant consequences. Here customers are trying to find information about products that can be used to assess the risks that will be obtained when they consumed. Negative consequences that can be controlled will be perceived to have a small probability so that the risk on the product will be small. The more a person can control the negative consequences that will be accepted the less risk will be perceived (Mandel, 2003). Thus, risk reduction in a product can be minimized through knowledge as well as customer information on products that are considered to increase customer perceived value.

The higher the uncertainty and consequences the customer receives, the lower the customer perceived value of the e-toll. However, if lower, the uncertainty and risk consequences are received by someone, the higher the customer perceived value of e-toll. The result of this study is in accordance with Pavlou's opinion that perceived risk plays a strong role to reduce the interest of customers to take part in transactions so that perceived risk is likely to negatively affect a transaction (Pavlou, 2003). However, if there is a consequence or uncertainty when transacting then it is not always the technology users do not want to reuse, but they will consider again to use or not use it. Based on the descriptive analysis in this study, respondents assessed the perceived risk that will be caused using e-toll is in the low range. Respondents consider that it is safe to deposit some money into e-toll because it has a low risk, so respondents have an interest in using e-toll services as a safe, fast, and efficient noncash transaction tool.

The results of this study indicated a relationship between perceived risk with purchase decision. The more customers have the knowledge about the perceived risk of e-toll, the easier the customer to make a purchase. The existence of customer knowledge on perceived risk based on customer experience on the use of a product to encourage consumers will give a positive effect on purchase decision. So, if the customers have the knowledge that the product to be purchased has a high risk then the customers will not buy the product. The presence of more experience about the product category will reduce the risks and costs of losses owned to increase the intention of interested products (Schiffman dan Kanuk, 2008).

Customers' knowledge based on prior experience of e-toll usage can be used by customers to assess and minimize the risk that customers will get from e-toll. Negative consequences that can be controlled by customers will result in the smaller customers perceived risk that impact on customer purchase decision on e-toll. This research is supported 
by previous research by Kim et. al., (2008) which stated that risk is considered to have an impact on customer decisions and customer purchasing behavior. The experience of using the product or service as well as information obtained by respondents related to products directly obtained through the product or service is the basis to help customers assess risk. With the customer's knowledge of risk assessment will affect the purchase decision.

\subsection{Customer perceived value positively influences purchase decision}

From the results of this study indicated that there was a positive relationship between customer perceived value and purchase decision. These results showed that if customer's knowledge on customer perceived value increases then the purchase decision will increase as well. This explains that the more customers have the knowledge on customer perceived value of e-toll the faster the customers take purchase decision. This study supports the research that has been done by Chen and Chang (2012) which stated that customer perceived value positively influenced customer purchase decision. In making e-toll purchases, customers will consider the value that will be obtained from the number of costs incurred. Associated with the respondent's answer and in general, that any purchase of any product related to the service, the customer will consider the customer perceived value of a product more deeply.

Based on the result of research can be seen that customer perceived value influenced the purchase decision (Chen and Cheng, 2012). Furthermore, Sweeney and Soutar (2001), disclosed poor customer perceived value can lead to loss of customer purchase decision. If the customers perceive that the value of the product is higher, they are more likely to buy the product. If connected, the characteristics of respondents and the results of respondents' answers indicated that the more respondents have more knowledge on customer perceived value then the respondents will increasingly intend to make a purchase. Chen and Dubinsky (2003)showed that customer perceived value or perceived value influenced customers when they buy a product.

The customer purchase decision depends on the customer perceived value of the customer on the product, which indicated a positive relationship between customer perceived value and purchase decision (Kotler and Gertner, 2002). Ailawadi and Keller (2004) assumed that customer perceived value can be used to direct customers to find customers' wishes, requests, and exchange rates for goods or services when deciding whether to buy a product or not. The perceived value is the customer's subjective perception (Dumana, 2005). It is relevant to the emotional response and consumption experience of consumption and the influence of customer behavior in the future. High customer perceived value leads to high customer purchase decision (Pickett-Baker and Ozaki, 2008).

\subsection{Managerial Implications}

Based on the results of this study, several things that need to be considered by e-toll issuers in attracting customers to use e-toll. E-toll issuers need to make their target market intend to use e-toll. The customer's attitude toward e-toll needs to be paid attention by e-toll issuers in selling e-toll to customers. Creating a positive attitude of customers can be performed for example through advertisements. In particular, these ads are emphasized on the benefits of e-toll. Benefits that can be highlighted from e-toll include customers will be easy in transactions at toll gates where customers do not need to carry money when transacting. Another benefit that can be highlighted from e-toll is the e-toll customers do not have the long queue when transacting at toll gates. If customers do not queue at the toll gates, customers can avoid the wasted time and psychological factors where customers feel saturated in queuing up. 
Related to the perceived value of using e-toll, e-toll issuers need to pay attention to whether the value is indeed owned by e-toll. Specifically, toll road operators need to pay attention to e-toll infrastructure support. Toll road operators need to ensure no errors in e-toll machines. The error that can happen is when the customer does a transaction with e-toll but the e-toll machine cannot read/detect the e-toll. Maintenance and repair of the e-toll machine need to be maintained so that the quality of the machine is good. The easiness to top-up e-toll also needs to be considered. Because if the customers perceive that the e-toll is easy to top-up, then the customers perceive the value in the e-toll. Customers will perceive that to top-up the e-toll does not require complicated procedures. Currently, top-up the e-toll is accomplished by top-up in indomaret, alfamart, ATMs, and mobile networks. With this e-toll top-up method, customers will perceive laziness to top-up with that method.

From the results of this study indicated that there was a positive relationship between customer perceived value and purchase decision. These results showed that if customer's knowledge on customer perceived value increases then the purchase decision will increase as well. This explains that the more customers have the knowledge on customer perceived value of e-toll the faster the customers take purchase decision. This study supports the research that has been done by Chen and Chang (2012) which stated that customer perceived value positively influenced customer purchase decision. In making e-toll purchases, customers will consider the value that will be obtained from the number of costs incurred. Associated with the respondent's answer and in general, that any purchase of any product related to the service, the customer will consider the customer perceived value of a product more deeply.

Based on the result of research can be seen that customer perceived value influenced the purchase decision (Chen and Cheng, 2012). Furthermore, Sweeney and Soutar (2001), disclosed poor customer perceived value can lead to loss of customer purchase decision. If the customers perceive that the value of the product is higher, they are more likely to buy the product. If connected, the characteristics of respondents and the results of respondents' answers indicated that the more respondents have more knowledge on customer perceived value then the respondents will increasingly intend to make a purchase. Chen and Dubinsky (2003)showed that customer perceived value or perceived value influenced customers when they buy a product.

The customer purchase decision depends on the customer perceived value of the customer on the product, which indicated a positive relationship between customer perceived value and purchase decision (Kotler and Gertner, 2002). Ailawadi and Keller (2004) assumed that customer perceived value can be used to direct customers to find customers' wishes, requests, and exchange rates for goods or services when deciding whether to buy a product or not. The perceived value is the customer's subjective perception (Dumana, 2005). It is relevant to the emotional response and consumption experience of consumption and the influence of customer behavior in the future. High customer perceived value leads to high customer purchase decision (Pickett-Baker and Ozaki, 2008).

\section{Conclusions}

Implementation of RFID application in Indonesia was e-toll. The results of the analysis can be concluded that there was a significant direct influence perceived usefulness and perceived risk to the purchase decision e-toll. There was a significant indirect influence with customer perceived value, between perceived usefulness and brand image of the purchase decision etoll. There was a non-significant direct effect between the brand image on the purchase decision e-toll. There was a non-direct indirect effect with customer perceived value between 
perceived risk to purchase decision e-toll. E-toll publishers need to create their target market and provide flexible payment facilities either through ATM, e-banking or other facilities. The toll road operator must also provide e-toll support infrastructure, so there is no error transaction on the e-toll machine.

\section{Acknowledgements}

This work was supported by the Grant of international publication on DIPA 2017 University of Trunojoyo Madura. (SP DIPA-027.01.2. 401029/2017).

\section{References}

[1] Ailawadi, K. L., \& Keller, K. L. (2004). Understanding retail branding: conceptual insights and research priorities. Journal of retailing, 80(4), 331-342.

[2] Alwadi, A., Kilby, J., \& Gawanmeh, A. (2017). Tracking and automating a Library System Using Radio Frequency Identification Technology. International Journal on Smart Sensing \& Intelligent Systems, 10(2).

[3] Armstrong, G., \& Kotler, P. (2011). Introducción al marketing. Prentice Hall.

[4] Ataman, B., \& Ülengin, B. (2003). A note on the effect of brand image on sales. Journal of Product \& Brand Management, 12(4), 237-250.

[5] Chiang, C. F., \& Jang, S. S. (2007). The effects of perceived price and brand image on value and purchase intention: Leisure travelers' attitudes toward online hotel booking. Journal of Hospitality \& Leisure Marketing, 15(3), 49-69.

[6] Chen, Z., \& Dubinsky, A. J. (2003). A conceptual model of perceived customer value in e - commerce: A preliminary investigation. Psychology \& Marketing, 20(4), 323347.

[7] Chen, Y. S., \& Chang, C. H. (2012). Enhance green purchase intentions: The roles of green perceived value, green perceived risk, and green trust. Management Decision, 50(3), 502-520.

[8] Davis, F. D. (1989). Perceived usefulness, perceived ease of use, and user acceptance of information technology. MIS quarterly, 319-340.

[9] Dumana, T. Mattilab (2005). The Role of Affective Factors on Perceived Cruise Vacation Value. Tourism Management, 26(3), 321-323.

[10] Dhurat, A., Magal, P., Chheda, M., \& Ingle, D. (2014). Gateless electronic toll collection using RFID. IOSR Journal of Computer Engineering, 16, 73-80.

[11] Elkaseh, A. M., Wong, K. W., \& Fung, C. C. (2016). Perceived ease of use and perceived usefulness of social media for e-learning in Libyan higher education: a structural equation modeling analysis. International Journal of Information and Education Technology, 6(3), 192.

[12] Fianto, A. Y. A., Hadiwidjojo, D., \& Aisjah, S. (2014). The influence of brand image on purchase behaviour through brand trust. Business Management and Strategy, 5(2), 58.

[13] Godey, B., Pederzoli, D., Aiello, G., Donvito, R., Chan, P., Oh, H., ... \& Weitz, B. (2012). Brand and country-of-origin effect on consumers' decision to purchase luxury products. Journal of Business research, 65(10), 1461-1470.

[14] Ghozali, I. (2005). Structural Equation Modeling Edisi 2. Semarang : Badan Penerbit UNDIP. 
[15] Hirunyawipada, T., \& Paswan, A. K. (2006). Consumer innovativeness and perceived risk: implications for high technology product adoption. Journal of consumer marketing, 23(4), 182-198.

[16] Juniwati. (2014). Influence of Perceived usefulness, Ease of Use, Risk on Attitude and Intention to Shop Online. European Journal of Business and Management. Vol.6, No.27

[17] Kim, D. J., Ferrin, D. L., \& Rao, H. R. (2008). A trust-based consumer decisionmaking model in electronic commerce: The role of trust, perceived risk, and their antecedents. Decision support systems, 44(2), 544-564.

[18] Kuisma, T., Laukkanen, T., \& Hiltunen, M. (2007). Mapping the reasons for resistance to Internet banking: A means-end approach. International Journal of Information Management, 27(2), 75-85.

[19] Kotler, P., \& Gertner, D. (2002). Country as brand, product, and beyond: A place marketing and brand management perspective. Journal of brand management, 9(4), 249-261.

[20] Kotler, P., \& Keller, K. L. (2009). Marketing management (13th end). New Jersey.

[21] Loudon, D., \& Della Bitta, A. J. (1988). Consumer behaviour: Concept and Cases. Mc Graw-Hills Pvt Ltd., New Delhi,.

[22] Low, G. S., \& Lamb Jr, C. W. (2000). The measurement and dimensionality of brand associations. Journal of Product \& Brand Management, 9(6), 350-370.

[23] Lee, K. S., \& Tan, S. J. (2003). E-retailing versus physical retailing: A theoretical model and empirical test of consumer choice. Journal of Business Research, 56(11), 877-885.

[24] Lien, C. H., Wen, M. J., Huang, L. C., \& Wu, K. L. (2015). Online hotel booking: The effects of brand image, price, trust and value on purchase intentions. Asia Pacific Management Review, 20(4), 210-218.

[25] Liu, C. R., Liu, H. K., \& Lin, W. R. (2015). Constructing customer - based museums brand equity model: The mediating role of brand value. International Journal of Tourism Research, 17(3), 229-238.

[26] Littler, D., \& Melanthiou, D. (2006). Consumer perceptions of risk and uncertainty and the implications for behaviour towards innovative retail services: the case of internet banking. Journal of retailing and consumer services, 13(6), 431-443.

[27] Mandel, N. (2003). Shifting selves and decision making: The effects of self-construal priming on consumer risk-taking. Journal of Consumer Research, 30(1), 30-40.

[28] Nam, W. H., Kim, T., Hong, E. M., Choi, J. Y., \& Kim, J. T. (2017). A Wireless Sensor Network (WSN) application for irrigation facilities management based on Information and Communication Technologies (ICTs). Computers and Electronics in Agriculture, 143, 185-192.

[29] Nandan, S. (2005). An exploration of the brand identity-brand image linkage: A communications perspective. Journal of Brand Management, 12(4), 264-278.

[30] Pavlou, P. (2001). Integrating trust in electronic commerce with the technology acceptance model: model development and validation. Amcis 2001 proceedings, 159.

[31] Pavlou, P. A. (2003). Consumer acceptance of electronic commerce: Integrating trust and risk with the technology acceptance model. International journal of electronic commerce, 7(3), 101-134.

[32] Pires, G., Stanton, J., \& Eckford, A. (2004). Influences on the perceived risk of purchasing online. Journal of Consumer Behaviour, 4(2), 118-131. 
[33] Pickett-Baker, J., \& Ozaki, R. (2008). Pro-environmental products: marketing influence on consumer purchase decision. Journal of consumer marketing, 25(5), 281-293.

[34] Reza Jalilvand, M., \& Samiei, N. (2012). The effect of electronic word of mouth on brand image and purchase intention: An empirical study in the automobile industry in Iran. Marketing Intelligence \& Planning, 30(4), 460-476.

[35] Ryu, K., Lee, H. R., \& Gon Kim, W. (2012). The influence of the quality of the physical environment, food, and service on restaurant image, customer perceived value, customer satisfaction, and behavioral intentions. International Journal of Contemporary Hospitality Management, 24(2), 200-223.

[36] Romaniuk, J., \& Sharp, B. (2003). Measuring brand perceptions: Testing quantity and quality. Journal of Targeting, Measurement and Analysis for Marketing, 11(3), 218229.

[37] Rossi, P., Borges, A., \& Bakpayev, M. (2015). Private labels versus national brands: The effects of branding on sensory perceptions and purchase intentions. Journal of Retailing and Consumer Services, 27, 74-79.

[38] Schiffman, L., \& Kanuk, L. L. (2008). Consumer Behaviour 7th Edition (Perilaku Pelanggan). Jakarta: PT. Indeks.

[39] Osswald, S., Wurhofer, D., Trösterer, S., Beck, E., \& Tscheligi, M. (2012, October). Predicting information technology usage in the car: towards a car technology acceptance model. In Proceedings of the 4th International Conference on Automotive User Interfaces and Interactive Vehicular Applications (pp. 51-58). ACM.

[40] Sweeney, J. C., \& Soutar, G. N. (2001). Consumer perceived value: The development of a multiple item scale. Journal of retailing, 77(2), 203-220.

[41] Teas, R. K., \& Agarwal, S. (2000). The effects of extrinsic product cues on consumers' perceptions of quality, sacrifice, and value. Journal of the Academy of marketing Science, 28(2), 278-290.

[42] Want, R. (2004). The magic of RFID. Queue, 2(7), 40-48.

[43] Wu, P. C., Yeh, G. Y. Y., \& Hsiao, C. R. (2011). The effect of store image and service quality on brand image and purchase intention for private label brands. Australasian Marketing Journal (AMJ), 19(1), 30-39.

[44] Woods, J., Peterson, K., \& Hirst, C. (2003). Maturing open RFID applications will reshape SCM. Gartner Research, Stanford. 